\title{
PROGRESS TOWARD A PRELIMINARY KARST DEPRESSION DENSITY MAP FOR THE CONTERMINOUS UNITED STATES
}

\author{
Daniel H. Doctor
}

U.S. Geological Survey, Florence Bascom Geoscience Center, 12201 Sunrise Valley Drive, MS926A, Reston, Virginia,20192USA,dhdoctor@usgs.gov

Jeanne Jones

U.S. Geological Survey, Western Geographic Science Center, 350 N. Akron Rd., Moffett Field, California 94035, USA,jmjones@usgs.gov

\section{Nathan Wood}

U.S. Geological Survey, Western Geographic Science Center, 2130 SW 5th Avenue, Portland, Oregon 97201 USA nwood@usgs.gov

\section{Jeff Falgout}

U.S. Geological Survey, Advanced Research Computing (ARC) Group, Denver Federal Center, Mail Stop 302, Denver, Colorado 80225,USA,jfalgout@usgs.gov

\section{Natalya I. Rapstine}

U.S. Geological Survey, Advanced Research Computing (ARC) Group, Denver Federal Center, Mail Stop 302, Denver, Colorado 80225,USA,nrapstine@usgs.gov

\section{Abstract}

Most methods for the assessment of sinkhole hazard susceptibility are predicated upon knowledge of preexisting closed depressions in karst areas. In the United States (U.S.), inventories of existing karst depressions are piecemeal, and are often obtained through inconsistent methodologies applied at the state or county level and at various scales. Here, we present a first attempt at defining a karst closed depression inventory across the conterminous U.S. using a common methodology. Automated algorithms for extraction of closed depressions from 1/3 arc-second (approximately $10 \mathrm{~m}$ resolution) National Elevation Dataset (NED) were run on the U.S. Geological Survey (USGS) "Yeti" high-performance computing cluster. The full NED was first conditioned to reduce the creation of artificial closed depressions by breaching digital dams at road and stream crossings, using the flowlines and transportation route vectors from the USGS National Map. The resulting depressions were selected according to location within geologic units having the potential for karst, and screened for occurrence in areas of developed land, open water and wetlands, and areas of glacial and alluvial sediment cover. The results were used as the input to create a nationwide depression density map. Our results were compared with karst depression density maps for diverse karst regions within states that have existing closed depression inventories. The individual state-scale maps compared favorably to the results obtained from the method applied universally across the nation and illustrated regional sinkhole hotspots in known areas of well-developed karst. Limitations of the automated method includes false positive depressions resulting from artifacts generated during the computer processing of the elevation models, and inclusion of depressions resulting from non-karst geomorphic processes. More thorough examination of the screening criteria for depressions is required.

\section{Introduction}

On the map "Engineering Aspects of Karst", William E. Davies et al. (1984) depicted regions of the United States prone to karst development based upon bedrock geology that host karst features - most notably caves - of various dimension and depth. In addition, Davies et al. (1984) included fourteen zones roughly outlined by dashed lines as "areas in which extensive historical subsidence has occurred." Since publication of that map, there have been numerous case studies on subsidence in karst regions across the United States, as well as regional or state-scale maps produced that portray karst subsidence features (Kuniansky et al., 2016). The most recent effort toward a national-scale synthesis of karst was by Weary and Doctor (2014), which provided digital geospatial data depicting bedrock geology with potential for karst feature development both near the surface and in the subsurface. While the map and database of Weary and Doc- 
tor (2014) provided an improvement in the resolution, scope, and accessibility of the map by Davies and others (1984), Weary and Doctor (2014) did not depict the relative degree of karst development in any given region. To do so would have required accumulated geospatial data and analysis of surface karst depressions (sinkholes and dolines) across the United States, and those data did not exist for the great majority of states.

The goal of the present study is to produce just such a dataset on the occurrence of closed depressions in karst areas at the national scale. The methodology for doing so is based on analysis of digital elevation models (DEMs) with consistent resolution that would permit extraction of closed depressions of dimensions known to reflect karst development. Once extracted, the dataset of surficial closed depressions can be used for creation of a map that shows the variations in density of surface depressions across the landscape. Such a map is useful for depicting the relative degree of karst development within areas geologically prone to karst development and may inform land managers as to potential subsidence hazards and water resource vulnerability.

\section{Methods}

To automate the delineation of closed surface depressions, digital elevation models (DEMs) at 1/3 arc-second (ap- proximately $10 \mathrm{~m}$ ) resolution, road line vector data, and National Hydrologic Dataset (NHD) stream line vector data were obtained from the U.S. Geological Survey National Map dataset (https://viewer.nationalmap.gov/ba$\underline{\text { sic/)}) . ~ T h e s e ~ d a t a ~ w e r e ~ u s e d ~ a s ~ t h e ~ i n p u t s ~ f o r ~ t h e ~ a u t o m a t e d ~}$ processing for extraction of closed depressions. The extraction of the depressions from the DEMs was conducted using a modified version of the Level Set tools developed by Wu et al. (2019) to extract sinks and delineate depression contours. A flow chart illustrating the processing is shown in Figure 1. The first step in the tool is "filling" the closed depressions in the DEM according to a hydrologic routing algorithm in which stream flow is forced to flow out across all edges of the elevation surface. As a result of this process, wherever flow is obstructed by a cell in the DEM of lower elevation than all surrounding cells, the elevation of that cell is raised to the elevation of the next lowest cell until flow can continue to spill out of the depression. This artificial filling process occurred without regard to natural or artificial depressions, and without regard to artificial obstructions to stream flow. Thus, wherever streams pass beneath roads or other surface obstructions (such as beneath bridges and through culverts), these locations act as "digital dams" to the flow routing, and cause filling of artificial closed depressions (digital reservoirs) behind the obstructions (Doctor and Young, 2013).

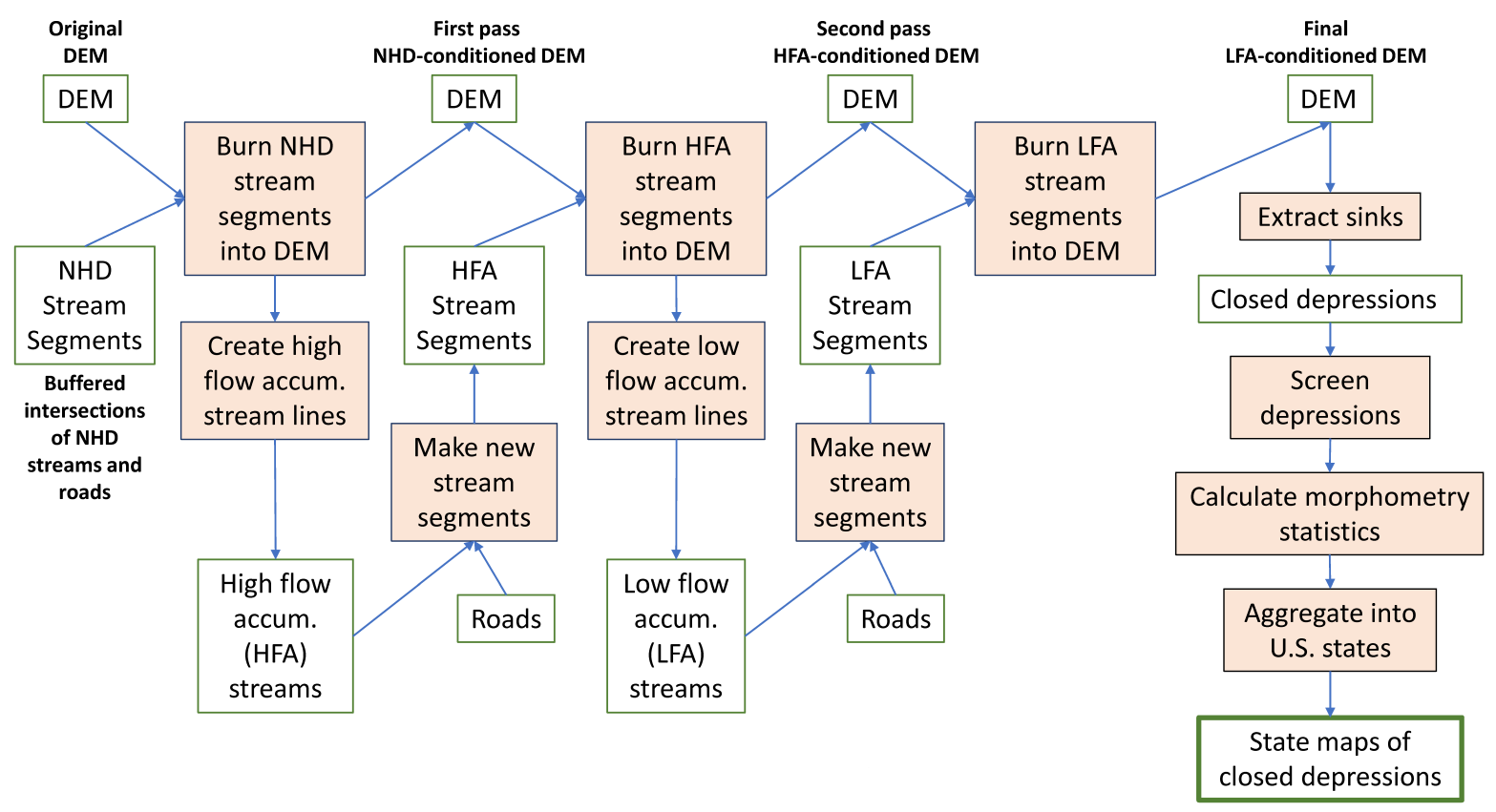

Figure 1. Flow chart illustrating the processing steps taken to condition the DEMs after progressive removal of digital dams, and subsequent definition of closed depressions. 


\section{Pre-conditioning of DEMs to Reduce Creation of Artificial Depressions}

To avoid the creation of artificial depressions, the DEMs were first conditioned to breach these digital dams using the HydroCutter custom ArcGIS ${ }^{\circledR}$ toolbox developed by Wall et al. (2015) to locate and then breach the digital dams (any use of trade, firm, or product names is for descriptive purposes only and does not imply endorsement by the U.S. Government.).

In order to facilitate operation on DEMs for the entire conterminous United States (CONUS) the HydroCutter tools (Wall et al., 2015) needed to be reworked and optimized to operate on large datasets. The code was redesigned and expanded to iterate over a set of input data (road vectors, stream vectors, and 1-degree DEM areas) that had been pre-processed by additional code to adhere to a consistent format. The basic steps of the HydroCutter toolbox formed the core of the automated DEM conditioning to iteratively recondition the original digital elevation models (DEM) by removing digital dams caused by culverts at road and stream intersections.

After conditioning, the modified Level Set code of Wu et al. (2019) was run on the DEMs to extract closed depressions. Conditioning and extracting depressions from over $900 \mathrm{DEMs}$ of $1^{\circ} \times 1^{\circ}$ area required computing power beyond a single laptop or desktop workstation. We considered both cloud computing and supercomputing options for generating the depressions, since both options would provide access to multiple servers with large amounts of random-access memory (RAM) and file storage. We chose the USGS Advanced Research Computing Center's "Yeti" Supercomputer (https://www.usgs. gov/core-science-systems/sas/arc) for ease of use, substantial shared file storage, and no cost of use. On Yeti, we could allocate nodes with 64 GB of RAM, customize each with specific geospatial tools running different versions of Python, and process multiple jobs in parallel. Processing ran for over 12,000 hours on more than 6600 cores. Total data storage for the processing on 927 DEMs was about 5.1 TBytes.

\section{Retention of Depressions in Karst Areas}

The resulting geospatial layers of closed depressions were screened to retain only those features occurring within areas of potential karst or pseudokarst and then grouped by state. This was achieved by intersecting the depression polygons with the layers of carbonates, evap- orites, and volcanic pseudokarst from the national karst database of Weary and Doctor (2014). Based on the scale of the original map unit areas being generally 1:500,000 or smaller, a $1 \mathrm{~km}$ buffer was added to the edges of the potential karst unit polygons. All depressions intersected within the buffered polygon areas were retained, and all others excluded.

Removal of Depressions According to Geometry The settings applied to the level-set algorithm of $\mathrm{Wu}$ et al. (2019) for defining depressions were a minimum depth threshold of $2 \mathrm{~m}$, and a slicing interval of $2 \mathrm{~m}$. A $2 \mathrm{~m}$ depth threshold was chosen since the root mean squared vertical error (RMSe) of the seamless $1 / 3$ arcsecond DEMs was determined to be $1.55 \mathrm{~m}$ as of 2013 (Gesch et al., 2014), and is continually improving with greater lidar coverage of the nation (Archuleta et al., 2017). In addition, a median filter smoothing function was applied with a kernel radius of $30 \mathrm{~m}$ to facilitate extraction of depressions with a minimum size threshold of 5 pixels $\left(500 \mathrm{~m}^{2}\right)$.

The depression polygons were also screened according to the following geometric shape criteria:

1. Polygons of area less than $600 \mathrm{~m}^{2}$ and less than $2 \mathrm{~m}$ maximum depth were excluded to avoid spurious depressions that may have occurred near the minimum size threshold.

2. Polygons of purely rectangular shape and of 1-pixel $(10 \mathrm{~m})$ width were excluded and considered to be artifacts of the digital processing.

Additional geometric shape criteria are still being evaluated for optimization of filtering of depressions. Initial inspection of the data indicates that different shape criteria may need to be applied to depressions in different geological or hydrological settings. This is a subject of future work; however, to take a conservative approach we applied several other means of screening out depressions according to multiple land cover and geologic attributes for which data were available.

\section{Removal of Depressions According to Land Classification}

Six classifications of the $30 \mathrm{~m}$ resolution National Land Cover Database (NLCD) (Yang et al., 2018) were used to exclude depressions as follows: Open Water (Class 11), Low Intensity Developed (Class 22), Medium Intensity Developed (Class 23), High Intensity Developed (Class 
24), Woody Wetlands (Class 90), and Emergent Herbaceous Wetlands (Class 91). The cells of these six classes in the NLCD CONUS raster (available at https://www.mrlc. gov/data/nlcd-2016-land-cover-conus) were converted to polygons, and closed depressions were removed wherever they intersected these polygons. Using the NLCD codes for developed land, three categories of developed land were selected as an indicator of mapped impervious surfaces: low intensity, medium intensity, and high intensity development, where intensity refers to the degree of light reflection off impervious surfaces on satellite imagery. Depressions were not removed from the class of Developed, Open Space (Class 21) to allow for depressions in areas such as parks, golf courses, cemeteries, etc. to be retained. Intersection with the NLCD classes for wetlands and open water avoided the inclusion of permanently flooded closed depressions which are generally unlikely to be of concern for assessment of sinkhole collapse.

In addition, depressions were removed that intersected a $50 \mathrm{~m}$ buffer around road and stream vector lines. The justification for removal of depressions within a $50 \mathrm{~m}$ buffer of roads and streams was to avoid inclusion of manmade closed depressions as a result stormwater management along roads such as ditches and retention basins, and to avoid anomalies in the elevation models due to inaccuracies in locations of incised stream channels.

\section{Removal of Depressions in Glacial and Alluvial Geologic Units}

Numerous depression polygons were generated in river floodplains having alluvial deposits, as well in areas covered by glacial till deposits greater than 50 feet $(\sim 15 \mathrm{~m})$ in thickness. To remove these depressions from being considered as karst depressions, the depressions were intersected with layers obtained from two sources: 1) the Natural Resources Conservation Service (NRCS) gridded soil survey (gSSURGO) data with soil polygons susceptible to flooding of any frequency to represent stream alluvium, and 2) glacial material coverage of Soller et al. (2012). The glacial deposit polygons obtained from the data provided by Soller et al. (2012) were used to screen for depressions in areas of coarse-grained stratified glacial sediment and any type of glacial sediment greater than $50 \mathrm{ft}(\sim 15 \mathrm{~m})$ in thickness.

\section{Creation of Karst Density Maps}

The pre-screened polygons were then converted to centroids and used to create density maps of closed depres- sion locations. Depressions density per square kilometer was calculated using the Point Density tool within the Spatial Analyst Toolbox in ArcMap ${ }^{\circledR}$ (v10.5). The applied tool settings used a circular moving window with a radius of $1 \mathrm{~km}$, and results were written to a grid with cells of $1 \mathrm{~km}^{2}$ area. As a result of smoothing along the moving window, the density value assigned to any grid cell is the number of points counted within the circular moving window divided by the area of the circle with radius $1 \mathrm{~km}$, or $3.14 \mathrm{~km}^{2}$. Therefore, the density values are not integers (i.e., a count of points within each $1 \mathrm{~km}$ grid cell), but instead may be fractional values.

The decision to estimate the density on a $1 \mathrm{~km}$ grid was for practical reasons to balance the resolution of the grid against the resolution of the data, as well as to consider any comparative datasets in the future. Several other national-scale datasets are produced by the USGS and other agencies at $1 \mathrm{~km}$ grid resolution. A $30 \mathrm{~m}$ grid (with cell area $=900 \mathrm{~m}^{2}$ ) would have been too small to adequately capture the density of depressions, since the minimum area of an included depression was $600 \mathrm{~m}^{2}$ and depression areas did not overlap.

After calculation of point density rasters at $1 \mathrm{~km}$ grid resolution, the rasters were classified into 5 density classes using the Natural Breaks (Jenks) mode in ArcMap and assigned a numerical ranking of Very Low $=1$, Low $=2$, Medium=3, High=4, Very High=5 (values=0 were excluded). Each of the density rasters were then reclassified with the numeric integer values (1 to 5 ) assigned according to these classes.

\section{Comparison of Depression Density with Independent Datasets}

Independent datasets of closed depressions were obtained from State geological surveys and private citizen sources that have made the data available in a format compatible with a geographic information system (GIS) (links to the data sources are provided in the Appendix). No attempt was made to create new GIS data from digitization of existing paper or other fixed-scale maps. States that serve karst depression GIS data include Alabama (AL), Florida (FL), Iowa (IA), Kentucky (KY), Minnesota (MN), Missouri (MO), Ohio (OH), Pennsylvania (PA), Tennessee (TN), and Virginia (VA). Some of these data are polygons (KY, VA), but most are point data $(\mathrm{TN}$, PA, MN, IA, FL, AL, OH). 
For the purpose of this preliminary work, only those states having complete or nearly complete statewide coverage of depression data were included for comparison with the automated results. These states were AL, KY, MN, MO, TN, and VA. Fortunately, these states cover a broad range in climate and geological settings of karst areas in the eastern and mid-western U.S. (Weary and Doctor, 2014), thus providing a robust test of the performance of the automated routine.

Although the validation datasets from each state were generated using different methods, reclassifying the estimated density values into new classes provides internal consistency and normalization among the various datasets, thus allowing the results to be compared between states that have validation data available. Similarly, we have placed all density results within an individual state on the same 5-class numeric scale described above that is simple for ease of visualization and to facilitate comparison with the automated results.

\section{Results}

Maps of depression density at $1 \mathrm{~km}$ resolution for both the validation datasets and the automated depressions are shown in Figure 2 for four examples of the six selected states described above. In general, the automated method captured more numerous depressions within a broader areal extent than did the independently mapped datasets within each state; however, the density classification values were generally in good agreement.

\section{Comparison of Independent State Data with Automated Data}

In order to more objectively compare the depression density raster of each state's validation data and the depression density raster generated by the automated method, code was written to create a tool in ArcGIS that would facilitate the comparison between the two rasters. This tool compares the integer values between each cell in the two input rasters and generates a new comparison raster with integer values from 1 to 25 that corresponds to one of all possible combinations between the 1 to 5 rankings assigned to the input density rasters. The comparison raster was then mapped and evaluated for similarity according to a matrix as shown in Figure 3.

The results show general good agreement between the depressions defined by the automated process and those of the independent datasets obtained from individual states.
Green colors in Figure 3 indicate good agreement, whereas yellow and orange colors represent poorer agreement, and red indicates no agreement. For example, if a grid cell was classified as having a very high (class 5) density in the state depression density map and was classified as very low (class 1) in the automated depression density map, the resulting comparison value would be a numeric factor 5 and would fall in the lower left corner of the comparison matrix. Conversely, if a grid cell was classified as having a very low (class 1 ) density in the state depression density map and was classified as very high (class 5) in the automated depression density map, the resulting comparison value would be a numeric factor of 21 and would fall in the upper right corner of the comparison matrix.

Percentage values within the matrix boxes refer to the number of cells showing agreement or disagreement relative to the entire number of cells compared. Percentage values beneath the matrices refer to the number of cells that were unique to each dataset, therefore not comparable between the two grids and thus separate from the comparison matrix results. An explanation for the comparison matrix is shown in the lower third of Figure 3.

\section{Discussion}

Discussion of the results of the automated depression extraction is facilitated by a closer examination of the density maps for the state of Alabama, as shown in Figure 4. The density map of automated depressions for Alabama shows cells with many more depressions over a broader area than the density of the depressions provided by the Geological Survey of Alabama. This observation is similar to several of the other states that have data that were compared to the automated results. Unlike the other states, Alabama shows the least amount of agreement between the automated results and the state validation data.

For example, $1 \%$ and $2 \%$ of cells fall into the comparison matrix zones in Figure 3 where the state data indicate a high to moderate depression density and the automated methods indicate a very low depression density (matrix categories 4 and 3, respectively). In addition, there is some lack of agreement where the state data indicated a low or very low depression density, and the automated method indicated a moderate to high depression density (categories 11, 16, and 17).

The map of the comparison matrix results shown in Figure 5 shows the areas of those discrepancies; they occur 


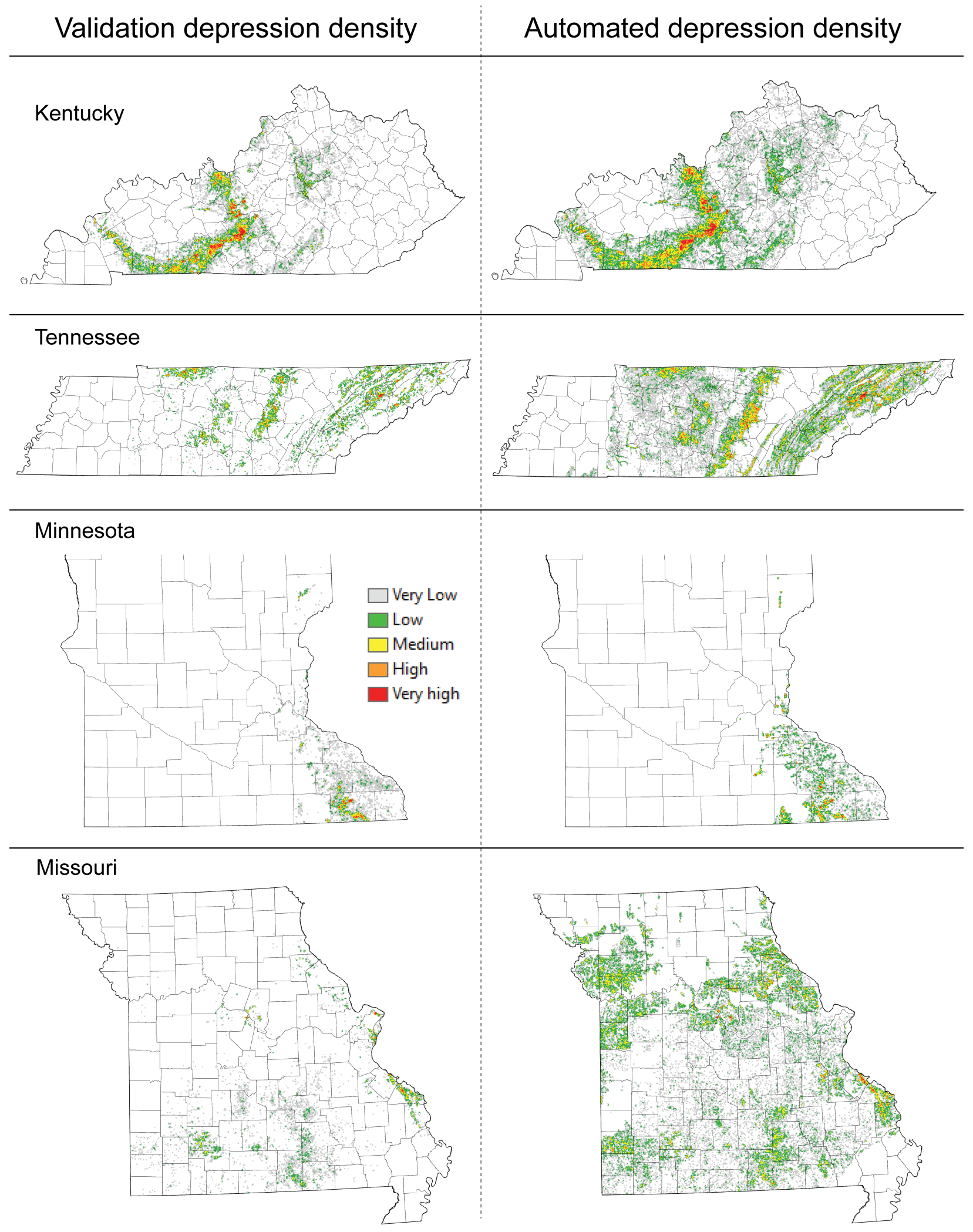

Figure 2. Maps of classified depression density at $1 \mathrm{~km}$ resolution for selected states that had independently mapped depression datasets for validation and comparison with the automated results. The color classification of depression density is the same for each map. 


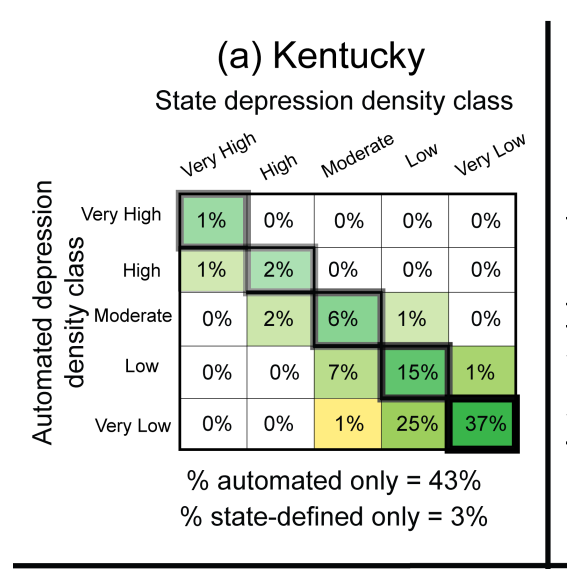

(d) Minnesota

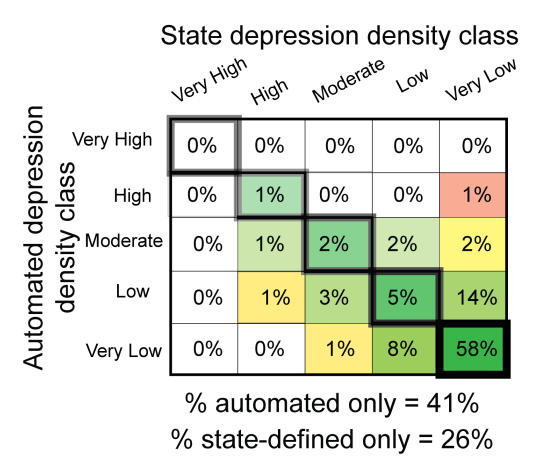

(b) Virginia

State depression density class

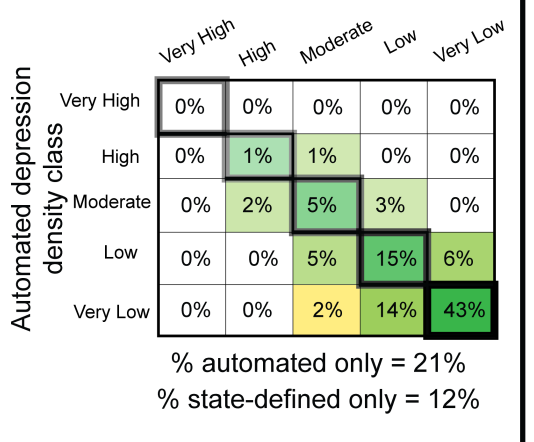

(e) Missouri

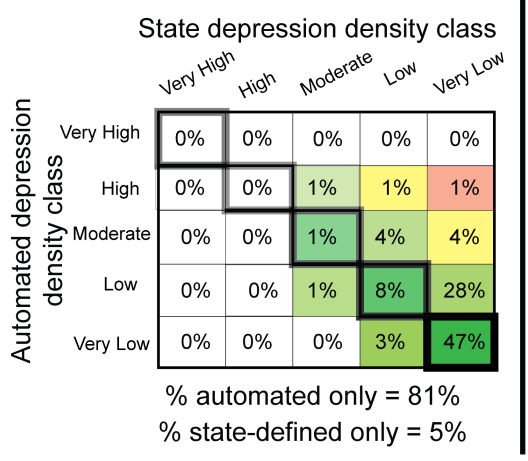

(c) Tennessee

State depression density class

\begin{tabular}{|c|c|c|c|c|c|}
\hline \multirow{6}{*}{ 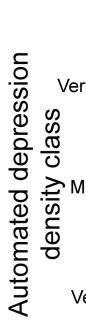 } & \multicolumn{2}{|c|}{ vert ${ }^{4 i g h}$ High } & \multicolumn{2}{|c|}{ Moderate Low } & veryto \\
\hline & $0 \%$ & $0 \%$ & $0 \%$ & $0 \%$ & $0 \%$ \\
\hline & $1 \%$ & $1 \%$ & $1 \%$ & $0 \%$ & $0 \%$ \\
\hline & $0 \%$ & $3 \%$ & $6 \%$ & $2 \%$ & $0 \%$ \\
\hline & $0 \%$ & $2 \%$ & $13 \%$ & $21 \%$ & $9 \%$ \\
\hline & $0 \%$ & $0 \%$ & $4 \%$ & $16 \%$ & $21 \%$ \\
\hline
\end{tabular}

\section{(f) Alabama}

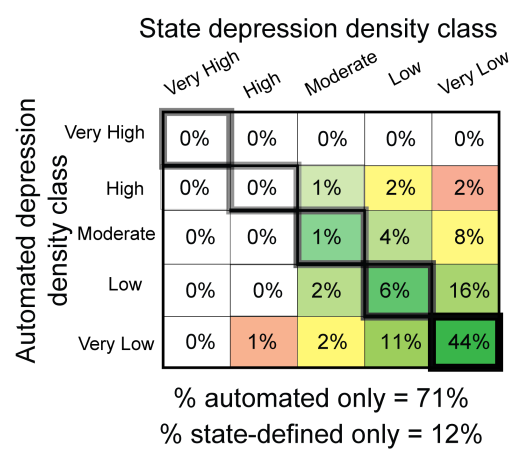

\section{EXPLANATION}

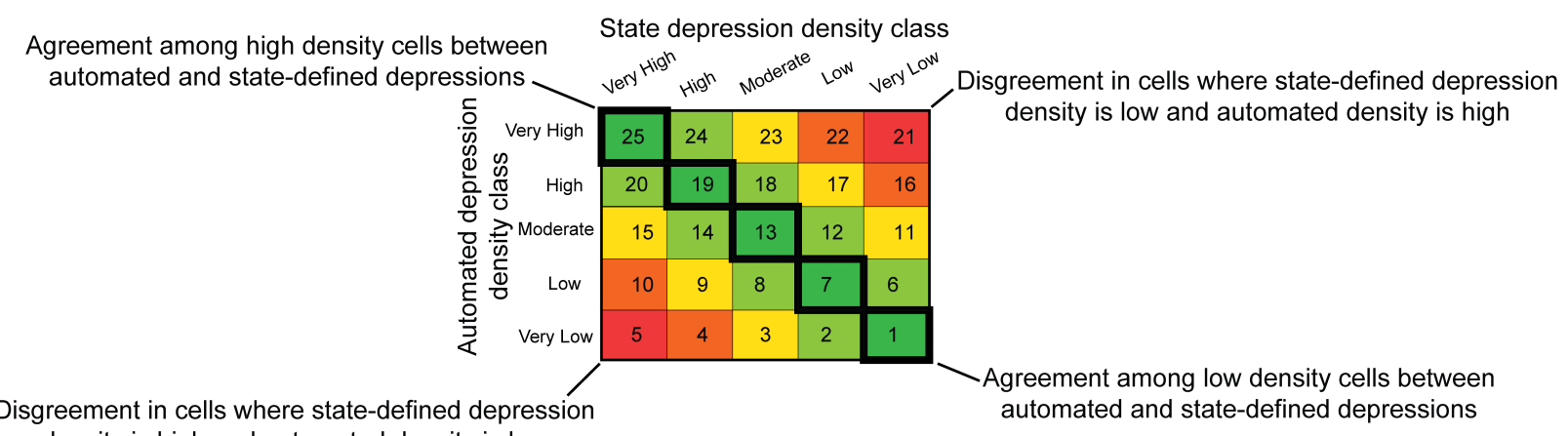
density is high and automated density is low

$$
\begin{gathered}
\% \text { automated only }=\text { Percentage of total cells containing only automated depressions } \\
\% \text { state-defined only }=\text { Percentage of total cells containing only state-defined depressions }
\end{gathered}
$$

Figure 3. Comparison matrices illustrating the relative degree of agreement between the depression density defined by independent state data, and the automated depression density. Results are shown for states where full or nearly full coverage of the state was available as an independent dataset. See text for details.

where more depressions were mapped via the automated routine than were included in the Alabama state survey data, primarily in two belts of karst in the northwestern part of the state, but also in the coastal plain units. The map of the comparison matrix results also shows where unique cells occur that were generated only in the state validation, or only in the automated results. The gray cells in Figure 4 shows where depression density greater than 0 only occurred in the automated data, while the black grid cells show locations where depression density greater than 0 only occurred in the validation data. For example, a large number of black cells occur in the 

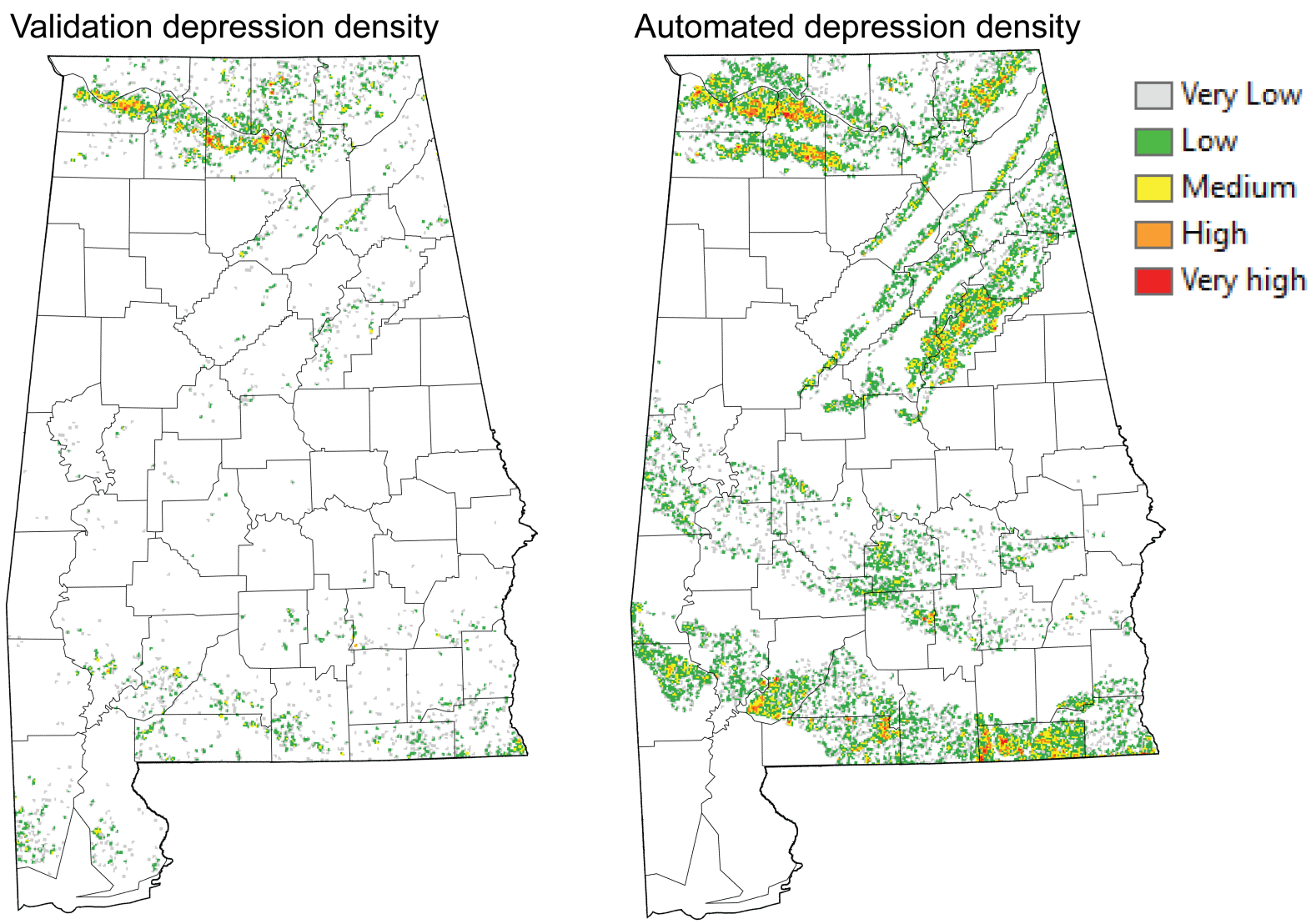

Figure 4. Depression density maps for depressions mapped independently by the Geological Survey of Alabama (left), and those obtained from the automated method (right). Note the greater density of the automated depressions in general, except for the southwestern panhandle; this area was not defined as containing carbonate bedrock in the original database of Weary and Doctor (2014).

southwestern panhandle. This discrepancy results because karst areas were not initially recognized within the two southernmost counties of Alabama within the dataset of Weary and Doctor (2014) that was used as a mask to eliminate depressions outside of potential karst areas (this is an oversight to be corrected in the next revision of the karst database for the U.S.).

\section{Preliminary National Depression Density Map}

A map of the depression "hotspots" across the U. S. generated according to this analysis is shown in Figure 6. Although preliminary, this map illustrates hotspots of closed depression density in several well-known karst areas around the U.S., such as the state of Florida, central and eastern Tennessee, the Pennyroyal Plateau in western Kentucky extending into southern Indiana, the Greenbrier Valley karst of West Virginia, central and southeastern Pennsylvania, north-central Ohio, southeastern Minne- sota and northeastern Iowa, and near to the Mississippi River in southwestern Illinois and southeastern Missouri (Palmer and Palmer, 2009). Less well-known in the karst literature are the prominent pseudokarstic terrains in volcanic rocks in the western U.S., or the evaporite karst areas in central Oklahoma.

Other areas that stand out on this map are where glacial deposits lie on top of carbonate bedrock, but that may in fact be falsely indicative of karst processes. These include some areas in northeastern Illinois, northern Wisconsin and Michigan, northern New York and western Vermont, and parts of east-central Ohio. Although depressions in areas of glacial cover thicker than $50 \mathrm{ft}(\sim 15 \mathrm{~m})$ were removed, those areas of less than $50 \mathrm{ft}(\sim 15 \mathrm{~m})$ or more patchy occurrences of glacial cover are included in the map. Many closed depressions can occur in glacial sediments as a result of periglacial processes such as melting of permafrost and 


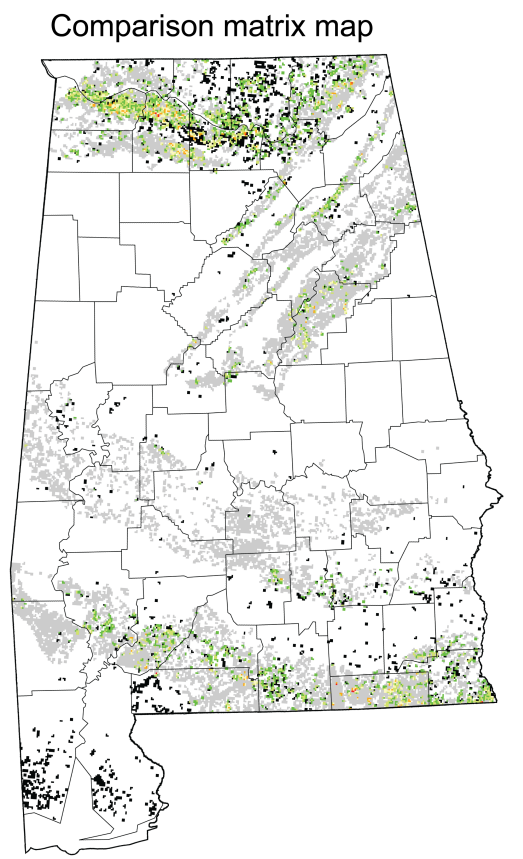

Validation : Automated 01-Very Low : Very Low $\square$ 02-Very Low : Low $\square$ 03-Very Low : Moderate $\square$ 04-Very Low: High 05-Very Low : Very High $\square$ 06-Low: Very Low $\square$ 07-Low: Low $\square$ 08-Low: Moderate $\square$ 09-Low: High $\square$ 10-Low: Very High $\square$ 11-Moderate : Very Low $\square$ 12-Moderate : Low $\square$ 13-Moderate: Moderate $\square$ 14-Moderate : High $\square$ 15-Moderate : Very High $\square$ 16-High : Very Low $\square$ 17-High : Low $\square$ 18-High: Moderate $\square$ 19-High : High $\square$ 20-High : Very High 21-Very High : Very Low $\square 22$-Very High : Low $\square$ 23-Very High : Moderate $\square$ 24-Very High : High $\square$ 25-Very High : Very High $\square$ Automated only - State-data only

Figure 5. Map of the comparison matrix of the classified density maps shown in Figure 4 , in which cells containing only depressions mapped by the state survey are shown in black. The other values correspond to the comparison matrix key as shown in Figure 3.

ice blocks. In addition, the southern Atlantic Coastal Plain shows a greater density of depressions than was expected, despite the removal of wetland and alluvial sediments. One factor not yet accounted for are depressions that form in aeolian sediments that overlie carbonate-bearing units such as those found within the Carolina Sand Hills, and areas in eastern Kansas. Aeolian depressions within Carolina Bays are also not yet screened out, as it can be difficult to distinguish between depressions formed from karst processed and those formed from purely aeolian processes in parts of North and South Carolina.

\section{Conclusion}

The results presented here indicate that the automated methods employed for extraction of closed depressions from the seamless USGS NED provide generally reliable data for computation of depression density maps in various karst regions across the U.S. Although many more individual closed depressions were identified from the automated methods than were contained in the state datasets, the $1 \mathrm{~km}$ grids of relative depression density obtained from the automated methods compared favorably to those calculated from independent datasets available for individual states.
At present no attempt has been made to screen for depressions formed through non-karst related geomorphic processes in areas underlain by carbonate or evaporite rocks that have glacial or other sediment cover (Figure 6); however, this will be the emphasis for future work and revision of the overall dataset.

\section{References}

Archuleta CM, Constance EW, Arundel ST, Lowe AJ, Mantey KS, Phillips LA. 2017. The National Map seamless digital elevation model specifications: U.S. Geological Survey Techniques and Methods, book 11, chap. B9, 39 p., https://doi.org/10.3133/ tm11B9.

Davies WE, Simpson JH, Ohlmacher GC, Kirk WS, Newton EG. 1984. Engineering aspects of karst: US Geological Survey, National Atlas of the United States of America, scale 1:7,500,000.

Doctor DH, Young JA. 2013. An evaluation of automated GIS tools for delineating karst sinkholes and closed depressions from 1-meter LIDAR-derived digital elevation data. In: Land L, Doctor DH, Stephenson JB, editors, Sinkholes and the Engineering and Environmental Impacts of Karst: Proceedings of the Thirteenth Multidisciplinary Conference, May 6-10, Carlsbad, New Mexico: NCKRI Symposium 2. Carlsbad (NM): National Cave and Karst Research Institute, p. 449-458.

Gesch DB, Oimoen MJ, Evans GA. 2014. Accuracy assessment of the U.S. Geological Survey National Elevation Dataset, and comparison with other large-area elevation datasets - SRTM and ASTER: U.S. Geological Survey Open-File Report 2014-1008, 10 p., https://doi.org/10.3133/ ofr20141008.

Kuniansky EL, Weary DJ, Kaufmann JE. 2016. The current status of mapping karst areas and availability of public sinkhole-risk resources in karst terrains of the United States. Hydrogeology Journal 24 (3): 613-624.

Palmer AN, Palmer MV, editors. 2009. Caves and karst of the U.S.A.; a guide to the significant cave and karst areas of the United States of America. Huntsville (AL): National Speleological Society, $446 \mathrm{p}$.

National Land Cover Database 2016, https://www.mrlc. 


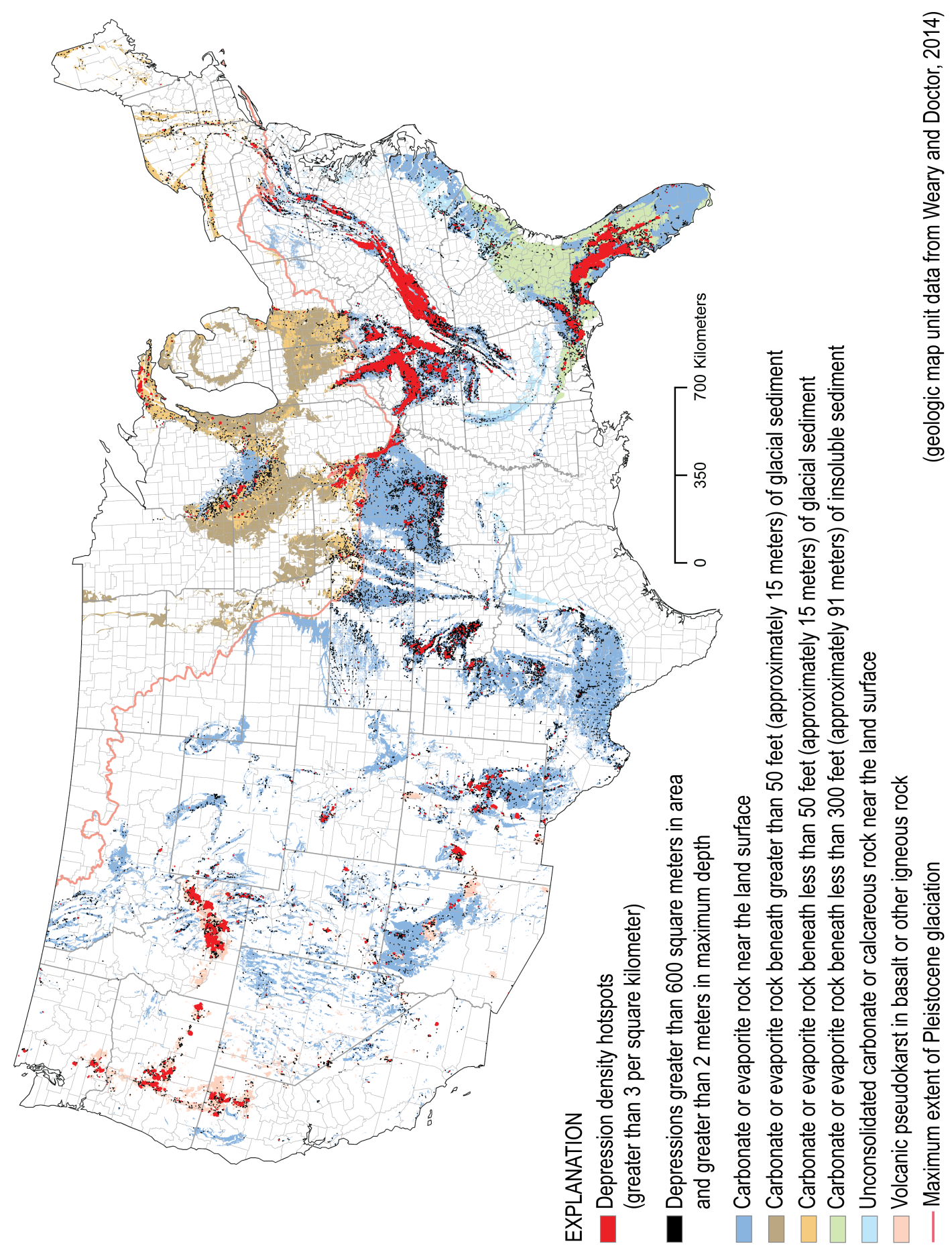

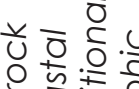

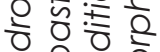

बं उ웅

क.u.

放

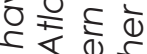

o $\leq \frac{1}{0}$

$\otimes$ \&

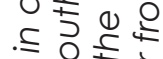

o

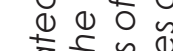

0 o 0

으웅

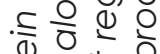

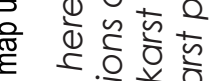

응

\&

i 0 d o 2

0 O

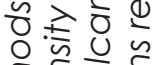

₹ 0 \%

ह

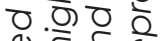

웡

है के

인

ठ원ㄷํㅇ

पे के

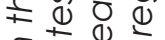

है워워

क为

잉

돈은

ริ잉

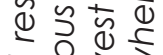

is 033

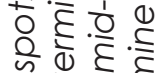

क

$\div 0 \div \frac{0}{9}$

ᄃ 140

을 느요

ه.

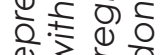

$03 \div 0$

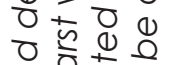

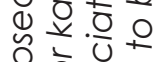

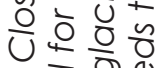

0.0 की

O. $\subseteq \subseteq 4$

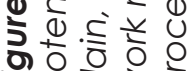

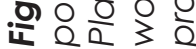


gov/data/nlcd-2016-land-cover-conus. Accessed October 27, 2019.

Soil Survey Staff. Gridded Soil Survey Geographic (gSSURGO) Database for the Conterminous United States. United States Department of Agriculture, Natural Resources Conservation Service. Available online at https://gdg.sc.egov. usda.gov/. Accessed October 27, 2019.

Soller DR, Packard PH, Garrity CP. 2012. Database for US Geological Survey Map I-1970, Map showing the thickness and character of Quaternary sediments in the glaciated United States east of the Rocky Mountains: US Geological Survey Data Series 656. http://pubs.usgs.gov/ds/656/. Accessed June 5, 2014.

The National Map, https://viewer.nationalmap.gov/ basic/. Accessed October 27, 2019.

US Geological Survey, National Geospatial Program, (2016), USGS National Hydrography Dataset (NHD) Best Resolution for 20160901 State or Territory FileGDB 10.1 Model Version 2.2.1: U.S. Geological Survey.

US Geological Survey (USGS), 2017, 1/3rd arcsecond Digital Elevation Models (DEMs) USGS National Map 3DEP Downloadable Data Collection: U.S. Geological Survey.

US Geological Survey, National Geospatial Technical Operations Center, 20190626, USGS National Transportation Dataset in FileGDB 10.1 format (published 20190626): U.S. Geological Survey.

US Geological Survey Advanced Research Computing, USGS Yeti Supercomputer: U.S. Geological Survey. https://doi.org/10.5066/F7D798MJ.

Wall J, Doctor DH, Terziotti S. 2015. A Semiautomated Tool for Reducing the Creation of False Closed Depressions from a Filled LIDAR-derived Digital Elevation Model. In: Doctor DH, Land L, and Stephenson JB, editors. Proceedings of the 14th Multidisciplinary Conference on Sinkholes and the Engineering and Environmental Impacts of Karst, Oct. 5-9, Rochester, Minnesota: NCKRI Symposium 5, National Cave and Karst Research Institute, pp. 255-262.

Weary DJ, Doctor DH. 2014, Karst in the United States:
A digital map compilation and database: U.S. Geological Survey Open-File Report 2014-1156, 23 p. https://doi.org/10.3133/ofr20141156.

Wu Q, Lane CR, Wang L, Vanderhoof MK, Christensen JR, Liu H. 2019. Efficient Delineation of Nested Depression Hierarchy in Digital Elevation Models for Hydrological Analysis Using Level-Set Method. JAWRA Journal of the American Water Resources Association, 55 (2): 354-368.

Yang L, Jin S, Danielson P, Homer C, Gass L, Case A, Costello C, Dewitz J, Fry J, Funk M, Grannemann B, Rigge M, Xian G. 2018. A New Generation of the United States National Land Cover Database: Requirements, Research Priorities, Design, and Implementation Strategies. ISPRS Journal of Photogrammetry and Remote Sensing 146 (12): 108-123. https://doi.org/10.1016/j. isprsjprs.2018.09.006.

\section{Appendix}

Online resources for state-wide sinkhole datasets.

Alabama sinkhole data:

https://www.gsa.state.al.us/gsa/geologic/hazards/ sinkholes\#sinkholeALMap

(accessed Jan. 2, 2020)

Minnesota karst feature inventory points: https:/gisdata.mn.gov/dataset/geos-karst-feature-inventory-pts

(accessed Jan. 2, 2020)

Missouri sinkhole data: http://data-msdis.opendata.arcgis.com/datasets/bb7ecb814719469a95151c2db3250397_0

(accessed Jan. 2, 2020)

Iowa karst and sinkholes: https://geodata.iowa.gov/dataset/karst-and-sinkholesiowa

(accessed Jan. 2, 2020)

Kentucky sinkhole data: https://www.uky.edu/KGS/gis/sinkpick.htm (accessed Jan. 2, 2020)

Ohio sinkholes and karst geology: http://geosurvey.ohiodnr.gov/geologic-hazards/karst- 
geology/karst-mapping

(accessed Jan. 2, 2020)

Pennsylvania karst feature data:

https://www.pasda.psu.edu/uci/DataSummary. aspx? dataset $=3073$

(accessed Jan. 2, 2020)

Tennessee sinkhole data:

https://tnlandforms.us/landforms/sinks.php

(accessed Jan. 2, 2020)

Virginia karst features data:

https://dmme.virginia.gov/gis/rest/services/DGMR/

KarstFeatures/MapServer

(accessed Jan. 2, 2020) 